\title{
Care management actions in the Family Health Strategy
}

\author{
Ações de gerência do cuidado na Estratégia Saúde da Família
}

\author{
Acciones de gestión de la atención en la Estrategia de Salud Familiar
}

\author{
Marcelo Costa Fernandes ${ }^{1}$, Lucilane Maria Sales da Silva ${ }^{2}$, Maria Rocineide Ferreira da Silva ${ }^{2}$, Thereza Maria \\ Magalhães Moreira ${ }^{2}$
}

Objective: to identify, from nurses' speeches, the actions that enable care management in the Family Health Strategy. Methods: descriptive study with a qualitative approach conducted with 32 nurses of primary care. It was used a semistructured interview as the data collection technique. The methodological process of the collective subject discourse was used to organize the data Results: from the nurses' speeches one identified the categories: complementary relationship between care and management; meeting with community health agents, a care management strategy in nurses' work; health education activities such as a care management action and a health information system as an essential tool for care Conclusion: it was possible to observe that nurses understood the importance of coordination and complementarity between the activities of the working process of care and management.

Descriptors: Public Health Nursing; Nursing Care; Management.

Objetivo: identificar, a partir dos discursos dos enfermeiros, as ações que viabilizam a gerência do cuidado na Estratégia Saúde da Família. Métodos: estudo descritivo, com abordagem qualitativa, realizado com 32 enfermeiros da atenção básica. Utilizou-se a entrevista semiestruturada como a técnica de coleta de dados. Recorreu-se ao processo metodológico do Discurso do Sujeito Coletivo para organização dos dados. Resultados: a partir das falas dos enfermeiros foi possível identificar as categorias: Relação de complementaridade entre o cuidar e o gerenciar; Reunião com os Agentes Comunitários de Saúde uma estratégia de gerência do cuidado no trabalho do enfermeiro; Atividades de educação em saúde como ação da gerência do cuidado e Sistema de informação em saúde como ferramenta essencial para a gerência do cuidado. Conclusão: foi possível identificar que os enfermeiros compreenderam a importância da articulação e complementaridade entre as atividades do processo de trabalho cuidar e gerenciar.

Descritores: Enfermagem em Saúde Pública; Cuidados de Enfermagem; Gerência.

Objetivo: identificar, a partir de los discursos de enfermeros, acciones que permitan la gestión de la atención en la Estrategia de Salud Familiar. Métodos: estudio descriptivo, con enfoque cualitativo, llevado a cabo con 32 enfermeros de la atención primaria. Se utilizó entrevista semiestructurada como técnica de recolección de datos. Se recorrió al proceso metodológico del Discurso del Sujeto Colectivo para organizarlos. Resultados: a partir de los discurso de los enfermeros, se identificaron las categorías: Relación complementaria entre cuidado y gestión; Encuentro con Agentes Comunitarios de Salud: una estrategia de gestión de la atención en el trabajo de enfermería; Actividades de educación en salud como acción de gestión de la atención y Sistema de información de salud como herramienta esencial para gestión de la atención. Conclusión: fue posible identificar que los enfermeros comprendieron la importancia de la articulación y complementariedad entre las actividades del proceso de trabajo cuidar y gestionar.

Descriptores: Enfermería en Salud Pública; Atención de Enfermería; Gerencia.

\footnotetext{
${ }^{1}$ Universidade Federal de Campina Grande. Cajazeiras, PB, Brazil.

${ }^{2}$ Universidade Estadual do Ceará. Fortaleza, CE, Brazil.

Corresponding author : Marcelo Costa Fernandes

Rua Coronel Alves Teixeira, 755, Apt. 103, Joaquim Távora, CEP: 60130-000. Fortaleza, CE, Brazil. E-mail: celo_cf@hotmail.com
} 


\section{Introduction}

The actions developed by the nursing staff in their daily practices are characterized primarily by direct care and management activities. However, these activities are influenced by the historical process that permeates the consolidation of this professional category, marked by the dichotomy of these practices.

Among the possible reasons for the differentiation between care and management, one can highlight the model proposed by Florence Nightingale in the nineteenth century, with the technical and social division of labor between nurses (direct care) and ladies nurses (indirect care) as well as by the precepts of administrative theories that consolidated the fragmentation of work and the separation between creation and execution, these elements that influenced the gap between these dimensions of the nursing working process ${ }^{(1)}$.

In order to break this split between care and management, nursing has been trying to develop actions where there is coordination and integration of direct care (care) with indirect care (management), that is, care management, which provides quality and integrity of activities, as well as satisfaction of users ${ }^{(2)}$.

Among the various health care settings in which nursing has the management of care, there is the Family Health Strategy, which was set up by the National Primary Care Policy as a key strategy to expand the service at this level of attention ${ }^{(3)}$.

However, the care management in the Family Health Strategy is still a practice that is not developed and not discussed on the national scenario(3), in addition to this, there are factors that separate care and management, especially due to the precariousness of the labor process and to the traditional care model. These characteristics harm the actions taken by nurses in this scenario of action and they can even generate on these professionals feelings of frustration especially for restriction of autonomy and little solving of the problems identified ${ }^{(4)}$.

In turn, when nursing develops care management in the Family Health Strategy, it ends up seeking assistance in all its nuances, as well as attention to the disease and consequently the possibility of comprehensiveness and strengthening of its actions. It also enables continuity of work efficiently and effectively, it overcomes fragmented welfare activities as well, and the simplified way of thinking and it highlights nursing care as the product of multiple interactions ${ }^{(5-6)}$.

Thus, the following guiding question is pointed out: What actions enable the care management identified in the discourse of nurses from the Family Health Strategy?

This restlessness provides a reflection on how nurses perceive their working process in the dimension of care management within primary care. The result of this research can also contribute to teaching, research and practice as it fosters the development of strategies that ensure a dialectical relationship between care and management, enabling the constructions of a more efficient and effective care plan as well as providing greater visibility to nursing, whether to the other members of the healthcare team, or to the social actors who seek health services for care $^{(7)}$. Therefore, the present investigation aims to identify, from nurses' speeches, the actions that enable the care management in the Family Health Strategy.

\section{Method}

This is a descriptive study with a qualitative approach, carried out in a primary care center in the city of Maracanaú-CE, Brazil. The municipality is part of the macro-region of Fortaleza and of the 3rd microregion of the Ceará State Health Department. It has 51 nurses from the Family Health Strategy, and 32 of them participated in this research. It was adopted as inclusion criteria only nurses who worked for more than twelve months in the primary care center. It is understood that this period is the minimum necessary for a nurse to be familiar with the dynamics of the scenario. One adopted as exclusion criteria the nurses 
who were on vacation or away on sick leave.

We used a semi-structured interview as the data collection technique. The interviews took place in the period between May and July 2012 in a place within the basic health unit. The suspension of data collection occurred from the moment when a theoretical saturation was identified.

To proceed with the ordination and organization of the empirical data, produced in the semi-structured interviews with selected nurses for this research, we used the methodological process of the Collective Subject Discourse, which is a tool that enables the representation of thought of a particular group. It is a methodology that proposes the sum of ideas in a non-numerical way, but operationalizing in a methodological way the expression of the collective thought through speech ${ }^{(8)}$.

The proposal of the collective subject discourse basically consists in analyzing the material built by a community through testimonials and then extracting their central ideas and key expressions. At the end, the content of responses with similar meanings is gathered in written summaries in the first person singular ${ }^{(8)}$.

Key expressions can be defined as fragments, excerpts or verbatim transcripts of speech that should be highlighted by the researcher and reveal the essence of the whole speech observed. The central idea is a name or linguistic expression that reveals and describes the most concise and precise way as possible, the meaning of each discourse analyzed and of each homogenous set of key expressions, which will generate later on the Collective Subject Discourse ${ }^{(8)}$.

Regarding the content analysis of the nurses' interviews, initially, there was a brief reading of the lines in order to understand all the transcripts. Subsequently, successive readings were necessary to make it possible to identify the units of meaning related to the guiding questions that composed the interview script. Then the key expressions were identified in each response, represented by the nurses' literal words. Out of these expressions, one built up the central ideas, which were organized and which will be presented on this research in four categories with the respective discourse.

It was carried out the clarification of the aims, methods, anticipated benefits and potential risks of the research. We also asked the study subjects to sign the free and informed consent form, informing the guaranteed anonymity and freedom to participate or withdraw their consent at any stage of the research.

The investigation began after the project was approved by the ethics committee of the State University of Ceará under the opinion No. 26907. The ethical and legal components are present at all stages of the research, in accordance with the Resolution 466/12 from the National Health Council.

\section{Results}

From the nurses' speeches about the actions that enable the care management, it was possible to identify four categories which will be presented and discussed with their respective Collective Subject Discourse. The first category was built from the interviews of eight nurses creating the following discourse: Category 01: complementary relationship between care and management. Collective Subject Discourse 01 - For me one complements the other, because when we create a schedule, we're thinking up front how it will be our care in the consultations, in an organized way or when you're going to make a gynecological prevention, we have to organize all the materials needed, as well as prenatal care, child care, vaccination and any other care. If you are a person without planning, who can't deal with your care activities, you will never be able to implement anything properly, it will always be something forced or when someone tells you to do, you only do it because someone said so, but sometimes you don't even know what you're doing, or the meaning of what you're doing. Logically this relationship between care and management is not perfect as there are several difficulties and activities for the nurse to perform, but from the moment that these actions are synchronized, I'll be able to organize my day to day, then having more time and availability to conduct care with higher quality.

Category 02 addresses nurse's meetings with 
the community health agents as a care management strategy. For the construction of the discourse of this category, nine nurses participated. Category 02: Meeting with community health agents, a care management strategy in nursing work. Collective Subject Discourse 02: There are meetings with the community health workers who are essential to the conduction of our actions. At the meetings we always discuss if there were any changes in the area, if there were any deaths, if there are any pregnant women to start prenatal care, if there are any children with delayed vaccination, any bedridden elderly person in need of a special chair to bathe, then we contact a social worker to help in the visit. All the home visits conducted are discussed at the meeting with the community health agents, and they also bring this demand. They say what the community needs and also pass on to the community our demands, such as campaigns to be carried out. At these meetings with the community health agents I can understand better my area, my people, their needs and everything. When I know the area I conduct the necessary interventions. If we didn't have meetings with health workers, the planning and the continuity of interventions would be very difficult.

Category 03 is about health education activities as nursing care management practices in the Family Health Strategy. Twelve interviews with nurses were used. Category 03: health education activities as a care management action. Collective Subject Discourse 03 All of our health education activities are planned before being carried out. In the waiting room I always try to approach a subject according to my care schedule before users enter in my room. On the day of prevention, I say something about the importance of prevention as well as about child care, prenatal care and other assistance. There are groups of pregnant women that we approach since delivery, the physiological changes of pregnancy, all the diseases that may be involved, the importance of all examinations, the importance of vaccination, the changes that can happen during pregnancy, care with the baby, sexual positions, the issue of sexuality and breastfeeding. In the School Health Program we also discuss about family planning, teen pregnancy and drug issues. We give several lectures for teenagers.

The last category discusses the health information system as an activity of nursing care management in the Family Health Strategy, and eight interviews with nurses were used. Category
04: Health Information System as an essential tool for care management. Collective Subject Discourse 04 - A fundamental action that we perform is the consolidation of the activities developed at the health center through the health information systems. I can also know the number of users who missed the consultations, the ones who didn't, I can know how many pregnant women I can attend in a month, how many did not come and with this piece of information and can draw up an action plan on the misconduct. I can observe from the health information system if there are any malnourished children, registered and accompanied hypertension and diabetes patients, if there were any strokes or heart attacks during the month. There is also the monitoring of the drug treatment of users with leprosy and tuberculosis.

\section{Discussion}

It was noticed in the Collective Subject Discourse 01 that nurses report the existence of coordination between care activities and management, that is, the care management as a key activity for the viability of the principles and guidelines of the Family Health Strategy.

It is understood that this strategy emerged in order to restructure the health model in Brazil, in order to overcome inequalities of access to the care network, strengthen basic attention and consequently increase the resolution and impact on the health of people and of communities, through multidisciplinary practices, planned with basis on local needs and through the health diagnosis of the territory ascribed ${ }^{(9)}$.

In order to have the development of these actions it is necessary that nurses are able to perform in their daily lives the care management, because it involves a dialectical relationship between the management know-how and care know-how. There is, with this practice, a set of relationships that results in a dynamic, situational and systemic process, which articulates the knowledge of management and care, enabling the existence of an interface between these two objects in the professional practice ${ }^{(2)}$. Thus there is the encouragement to a critical and reflexive view of the activities that nurses develop, allowing this 
category to appropriate from the philosophical work of the Family Health Strategy and implement changes in the pursuit of improving the lives of the population attended.

Thus, it is understood that management is an activity that leads to the implementation of work, because the target activity is the assistance and care guided by a certain quality standard, recognized by the service as desirable ${ }^{(10)}$. Therefore, the purpose of care management is to provide a systematized and quality care to the users of nursing and health services ${ }^{(2)}$, as well as promoting, as discussed, the Family Health Strategy as a proposal for the reorganization of primary care.

However, there are difficulties to perform the articulation between care and management activities by the nurse in the Family Health Strategy, according to the speech, and this relationship is not demanded by some health institutions, as they ultimately give greater emphasis to the management of services.

This split between the care and management dimensions intervene negatively in the nursing work process and consequently restricts the autonomy of these professionals in the field of primary care, which weakens the solving of problems identified, producing dissatisfaction of the population attended by health services $^{(4)}$.

Therefore, it is understood the need of interlacing and approach between care and management, that is, the care management within the nurse's actions in the Family Health Strategy in a dimension that goes beyond the technicality and incorporates the knowledge and attitudes of rational and sensitive order ${ }^{(11)}$.

The meeting with the community health agents contributes to the work of nurses in primary care from the perspective of complementarity and interdependence of actions, characterizing the multidisciplinary practices. Teamwork in the Family Health Strategy is at the forefront for changes of the health care model in a complex and dynamic socio-cultural reality. The articulation of different knowledge of professionals from primary care, which has the particularity of the presence of Community Health Agents, enables the construction of activities that transcend the rationality of curative care ${ }^{(12)}$.

However, it is clear in the Collective Subject Discourse 02 that the planning of care management actions conducted by nurses presents a certain dependence on information about the families included in the territory, which are passed on by the community health agents during scheduled meetings.

This reality is inconsistent with the duties of this professional at this level of attention because, according to the ordinance of primary care, nurses and other members of the healthcare team should participate in the process of territory definition and mapping of the area of action, identifying groups, families and individuals at risk and vulnerabilities ${ }^{(13)}$.

Still according to the ordinance of primary care, nurses are the professionals who must constantly have meetings with community health agents, since they must plan, manage and evaluate the actions taken by them and facilitate the relationship between the professionals from the Family Health Strategy and the community health agents, contributing to the planning of health care, qualification of access, bond, welcoming and orientation of the team's performance depending on the health priorities ${ }^{(13)}$.

It is understood that the meeting between nurses and community health agents is really important, since these professionals work in the territory of the family and they gradually establish a bond from the perspective of longitudinal attention, which promotes the construction of the care plan, but it is understood that nurses should not wait for community health agents to know the reality and the needs of the population attended in their health unit for the construction of care management of actions to be performed in that area.

It was identified according to the nurses' Collective Subject Discourse 03, activities of health education as a care management action because there is, according to the discourse of these professionals, 
an integration and coordination between the indirect care (planning) and direct care (guidance).

This discourse is in accordance with the National Policy of Basic Attention that reports to be an assignment from nurses and from other professionals of the Family Health Strategy the conduction of health education activities to the population attended, according to the team's planning ${ }^{(13)}$.

It is observed in this collective subject discourse that the main education activities reported by nurses as health care management practices were: waiting room, health groups and actions with teenagers at the School Health Program.

However, it is observed that all these health education activities are strongly influenced by a biomedical model, with emphasis on the prescriptive and authoritative aspects, besides presenting characteristics of traditional health education, with transmission of knowledge and experiences, where nurses expect users to absorb the contents taught without modifications and to reproduce them faithfully.

This traditional model of health education corresponds to the form of banking education, in which the role of nurses when they teach is to "fill" users (students) with content, transforming them into communication deposits. In this view, users are passive beings, so it is up to education to adapt them to reality ${ }^{(14)}$.

In this form of education subjects are educated with little reflection, and there is no incentive for creation, and nurses (educators) are also alienated because they are not adaptable and do not seek further knowledge, since they are not challenged by users (students). Education remains vertical, with nurses being considered superior beings who teach the ignorant ones ${ }^{(15)}$.

In this context, it is expected that health education activities can break away from these interventions directed to the biological dimensions of health and go on to develop practices that enhance the subjective, social and dialogical questions, in order to encourage the completeness of care provided and the emancipation of the social actors involved in these actions.

The educational activities in health proposed in the national policy of primary care aim to promote health and prevent aggravations, both individually and collectively, based on local needs. They also aim to raise the autonomy and empowerment of people, making them protagonists of the health, disease and care process ${ }^{(13)}$.

Thus, in this sense, it is understood that the health education activities in the Family Health Strategy as practices of care management, guided by the construction of knowledge through dialogue, will enable nurses and users to take active roles in the learning process with a critical-reflective view of the reality they live in ${ }^{(16)}$.

It is understood that the use of the Information Health System mentioned in the Collective Subject Discourse 04 is an essential tool for nursing care management in this area, for being an important strategy for the diagnosis of situations in order to provide more approximate interventions for the needs of the population attended.

The Health Information System is vital, as it enables the characterization of the population at risk and allows one to plan treatment strategies according to the needs and specificities of each population group $^{(17)}$.

However, the health education activities performed by nurses in the Family Health Strategy and the use of the Health Information System are linked to the sense of control of diseases and drug treatments, which reflects a practice in primary care, still focused on the hospital and the traditional model of health care.

It is noteworthy that according to the ordinance of primary care, the conduction of records in the Health Information System is not an specific assignment of nurses, but it is a common action to all the team members ${ }^{(13)}$. However, the reality in these services demonstrates that nurses are the professionals 
who take responsibility for the quality of the record in the Primary Care information systems, so this could already be a specific activity of this category, because it takes time and knowledge in the area, and it is important for the planning of care management actions to be performed at the health unit.

\section{Final Considerations}

During the analysis of this research it was possible to identify that the nurses from the Family Health Strategy understand the importance of the articulation and complementarity between the activities of the working process of care and management, that is, the conduction of care management in their daily lives as an essential practice in the development of their actions at this level of health care.

It stands out as the main tools for the conduction of care management, the meetings with community health agents, the health education activities and the use of the Health Information System.

This research has limitations regarding the conduction of a study at the Family Health Strategy of a single municipality, which makes it difficult to generalize the findings. It is believed that this study contributes to overcome the split between care and management in the daily nursing practice, as it presents action where this relationship of articulation is possible, which contributes to more critical and reflective activities, but it also encourages the development of tools that can solve the health problems of the population attended in the Family Health Strategy more efficiently and effectively.

Thus, there is a need to sensitize nurses inserted in teaching, research and practice for the development of new studies on care management, especially creating care technologies that are based on this dialectical relationship between care and management, and that can encourage the consolidation of primary care as a reorientation strategy of the care model.

\section{Collaborations}

Silva MRF and Moreira TMM contributed to the analysis, writing and review. Fernandes MC and Silva MS contributed to the project design, analysis, drafting, review and approval of the final version to be published.

\section{References}

1. JLG, Pestana AL, Guerrero P, Meirelles BSH, Erdmann AL. Práticas de enfermeiros na gerência do cuidado em enfermagem e saúde: revisão integrativa. Rev Bras Enferm. 2013; 66(2):257-63.

2. Christovam BP, Porto IS, Oliveira DC. Nursing care management in hospital settings: the building of a construct. Rev Esc Enferm USP. 2012; 46(3):73441.

3. Fernandes MC, Silva LMS. Nurse care management in the family health strategy: integrative review. Rev Rene. 2013; 14(2):438-47.

4. Fernandes MC, Silva LMS, Moreira TMM, Silva MRF. Factors involved in the management of nursing care: a descriptive study. Online Braz J Nurs. [Internet]. 2013 [cited 2014 Mar. 10]; 12(2):52233. Available from: http://www.objnursing.uff. br/index.php/nursing/article/view/4081/pdf

5. Backes DS, Erdmann AL, Lunardi VL, Lunardi WD, Erdmann RH. Despertando novas abordagens para a gerência do cuidado de enfermagem: estudo qualitativo. Online Braz J Nurs. [Internet]. 2009 [cited 2014 Feb. 12]; 8(2): [about 5 p.]. Available from: http://www. objnursing.uff.br/index.php/nursing/article/ view/j.1676-4285.2009.2407/527

6. Santos JLG, Lima MADS, Klock P, Erdmann AL. Conceptions of nurses on management of care in an emergency department-descriptive exploratory study. Online Braz J Nurs. [Internet]. 2012 [cited 2014 Apr. 11]; 11(1):101-14. Available from: http://www.objnursing.uff.br/index.php/ nursing/article/view/3580/pdf

7. Hausmann M, Peduzzi M. Articulação entre as dimensões gerencial e assistencial do processo de trabalho do enfermeiro. Texto Contexto Enferm. 2009; 18(2):258-65. 
8. Lefèvre F, Lefèvre AMC. O discurso do sujeito coletivo: um novo enfoque em pesquisa qualitativa (desdobramentos). Caxias do Sul: Educs; 2005.

9. Silva LA, Casotti CA Chaves SCL. A produção científica brasileira sobre a Estratégia Saúde da Família e a mudança no modelo de atenção. Ciênc Saúde Coletiva. 2013; 18(1):221-32.

10. Jonas LT, Rodrigues HC, Resck ZMR. A função gerencial do enfermeiro na Estratégia saúde da Família: limites e possibilidades. Rev APS. 2011; 14(1):28-38.

11. Montezelli JH, Peres AM, Bernardino E. Demandas institucionais e demandas do cuidado no gerenciamento de enfermeiros em um pronto socorro. Rev Bras Enferm. 2011; 64(2):348-54.

12. Pereira RCA, Rivera FJU, Artmann E. 0 trabalho multiprofissional na estratégia saúde da família: estudo sobre modalidades de equipes. Interface. 2013; 17(45):327-40.
13. Ministério da Saúde (BR). Portaria GM no. 2488, de 21 de outubro de 2011. Aprova a Política Nacional de Atenção Básica, estabelecendo a revisão de diretrizes e normas para a organização da Atenção Básica, para a Estratégia Saúde da Família e o Programa de Agentes Comunitários de Saúde. Brasília: Ministério da Saúde; 2011.

14. Freire P. Pedagogia do oprimido. 46a . ed. Rio de Janeiro: Paz e Terra; 2005.

15. Freire P. Educação e mudanças. 30a a ed. Rio de Janeiro: Paz e Terra; 2007.

16. Figueiredo MFS, Rodrigues-Neto JF, Leite MTS. Modelos aplicados às atividades de educação em saúde. Rev Bras Enferm. 2010; 63(1):117-21.

17. Zillmer JGV, Schwartz E, Muniz RM, Lima LM. Avaliação da completude das informações do hiperdia em uma Unidade Básica do Sul do Brasil. Rev Gaúcha Enferm. 2010; 31(2):240-6. 